UDK 579.25

\author{
A.G. Merlich, V.O. Ivanytsia, N.V. Korotaeva, M.A. Zlatogurska, \\ N.Yu. Vasylieva, D.O. Babenko, N.V. Limanska \\ Odesa National I.I. Mechnykov University, 2, Dvorianska str., 65082, Ukraine, \\ e-mail: limanska@gmail.com
}

\title{
LACTOBACILLUS PLANTARUM FROM BERRIES OF GRAPE CULTIVATED IN THE SOUTH OF UKRAINE
}

\begin{abstract}
The aim of the investigation was the isolation of Lactobacillus plantarum from berries of grape and the study of their genetic diversity. Materials and Methods. Lactic acid bacteria were isolated from berries of 14 grape cultivars grown in the south of Ukraine. PCR-assay and RAPD-PCR were used for L. plantarum identification and the study of their diversity. The reconstruction of phylogenetic tree of the studied strains was carried out with Matlab 7.0 program. Results. Lactobacilli have been isolated from 7 samples of must among 14 of the tested grape cultivars. $80 \%$ of the studied strains belonged to L. plantarum species. Groups of genetic similarity between L. plantarum strains have been revealed. In the phylogenetic tree four clusters of the strains grouped by their similarity were formed. The mentioned results allowed to conclude that L. plantarum strains from must of grape of different cultivars and territories of grape cultivation could show the genetic similarity. Opposite, some L. plantarum strains from one source of origin could demonstrate the genetic diversity.
\end{abstract}

Key words: lactic acid bacteria, grape must, RAPD-PCR.

Lactic acid bacteria of Lactobacillus genus inhabit various biotopes, including plant surfaces, where they survive as the representatives of epiphytic microbiota and can be characterized by the genetic diversity [3; 9 ; $13 ; 15]$. Insects fed on flowering grape are the important source of berry colonization [6]. Bacteria of Lactococcus, Leuconostoc and Lactobacillus genera have been revealed in gut of bees and wasps [11]. L. plantarum and Oenococcus oeni from the surfaces of grape berries cause malolactic fermentation in wine and in cases of uncontrolled fermentation they are responsible for "grape diseases". Usually malolactic fermentation begins in two-four weeks after the end of alcohol fermentation [2]. One of the consequences of this process is less acidity that occurs as a result of decarboxylation of malic acid to lactic acid. The controlled process of malolactic fermentation is desirable in wine-making, especially for acid wines, because it gives them

(C) A.G. Merlich, V.O. Ivanytsia, N.V. Korotaeva, M.A. Zlatogurska, N.Yu. Vasylieva,

D.O. Babenko, N.V. Limanska, 2013 
A.G. Merlich, V.O. Ivanytsia, N.V. Korotaeva, M.A. Zlatogurska, N.Yu. Vasylieva and others

more soft taste. For controlled malolactic fermentation, bacteria Oenococcus oeni are used as starter cultures. In case of using lactobacilli, there is a risk of their rapid growth resulting in non-desirable taste of wine [7].

The aim of the investigation was the isolation of Lactobacillus plantarum from grape must and the study of their genetic diversity.

\section{Materials and Methods}

Must from berries of 14 grape cultivars grown in the south of Ukraine in 2011-2012 (Pinot noir, Chardonnay, Riesling, Cardinal, Kishmish, Moldova, Dnistrovskyi rozhevyi, Kesha, Vostorg, Odesa souvenir, Lidia, Isabella, Cabernet Sauvignon and Muscat Hamburg) was incubated under the room temperature $\left(18-20{ }^{\circ} \mathrm{C}\right)$ for the natural fermentation process. The isolation of lactobacilli from grape must was carried out on $2-28^{\text {th }}$ days of fermentation. The quantity of lactobacilli $(\mathrm{CFU} / \mathrm{ml})$ in must was evaluated by inoculating MRS agar with serial dilutions of must, incubation at $30 € \mathrm{C}$ and counting the grown colonies [8]. All the inoculations have been carried out in 5 repeats.

The colonies with the typical for lactic acid bacteria morphology have been selected for the standard tests revealing their belonging to Lactobacillus genus. The next identification of Lactobacillus plantarum was carried out by the polymerase chain reaction (PCR) [5]. DNA was isolated by the heat lysis method in modification of Szegedi and Bottka (2002) [14]. PCR mixture contained $0.8 \mu \mathrm{l}$ of $\mathrm{Mg}^{++}(50 \mathrm{mM}$, AmpliSens, Russia), 2,0 $\mu \mathrm{l}$ of dNTP (4 mM each, SibEnzyme, Russia), $1.0 \mu \mathrm{l}$ of each primer (10 pmol), and $0.4 \mu \mathrm{l}$ of Taq-polymerase $(5 \mathrm{U} / \mu \mathrm{l})$ (Primetech, Belorussia) in a standard PCR buffer (10x) (Taq-polymerase buffer, SibEnzyme, Russia).

The genus specific primers LbLMA-1/R-161 to the sequence of 16 s rRNA: 5'-CTC AAA ACT AAA CAA AGT TTC-3' and 5'-CTT GTA CAC ACC GCC CGT TCA-3' were used [5]. For identification of Lactobacillus plantarum species the specific primers to gene recA of L. plantarum - planF ( $5^{\prime}$-CCG TTT ATG CGG AAC ACC TA-3') and pREV (5'-TCG GGA TTA CCA AAC ATC AC-3') were used [15]. The parameters of amplification were the next: $94{ }^{\circ} \mathrm{C}-3 \mathrm{~min}$ for the initial denaturation, after 30 cycles at $94{ }^{\circ} \mathrm{C}-30 \mathrm{~s}$, $55^{\circ} \mathrm{C}-10 \mathrm{~s}, 72{ }^{\circ} \mathrm{C}-30 \mathrm{~s}$, and final elongation at $72^{\circ} \mathrm{C}$ for 5 min [5]. PCR products were analyzed by electrophoresis in $1.5 \%$ agarose gel using TBE buffer with ethidium bromide (AmpliSens, Russia). Markers of molecular weight - pUC19 DNA/MspI 110, 147, 190, 242, 331, 404, 489, 501 b.p.; Lambda DNA/EcoRI+HindIII 564, 831, 947, 1375, 1584, 1904, 2027, 3530, 4268, 4973, 5148, 21226 b.p. (Fermentas, Lithuania) were used.

The control strains L. plantarum UCM B-2709 and L. plantarum UCM B-2694 from the Collection of Microorganisms of Zabolotny Institute of Microbiology and Virology were kindly provided by Professor Kovalenko N.K.

RAPD-PCR were carried out with L. plantarum strains isolated from must and from the control reference strains L. plantarum UCM B-2709 and L. plantarum UCM B-2694. 
The mixture for RAPD-PCR contained the next components: $1.0 \mu \mathrm{l}$ of a primer $\mathrm{M} 13$ (10 pmol), $0.8 \mu \mathrm{l}$ of $\mathrm{Mg}^{++}(50 \mathrm{mM}$, AmpliSens, Russia), $2.0 \mu \mathrm{l}$ of dNTP ( $4 \mathrm{mM}$ of each, SibEnzyme, Russia), and $0.4 \mu \mathrm{l}$ of Taqpolymerase $(5 \mathrm{U} / \mu \mathrm{l})$ (Primetech, Belorussia) in a standart PCR-buffer (10x) (Taq-polymerase buffer, SibEnzyme, Russia). Amplification was carried by the parameters described in Ben Omar et al. (2008). PCR-products were analyzed in $1 \%$ agarose gel using TAE buffer ( $40 \mathrm{~V}, 4$ hours). Gels were photographed with GelDoc system (BioRad, USA).

The reconstruction of phylogenetic tree of the studied strains was carried out with Matlab 7.0 program. Cluster analysis based on Spearman's correlation coefficient for measuring the distance between the objects and the method of Ward for constructing a hierarchical tree of binary clusters were used.

\section{Results and Discussion}

Lactobacilli were isolated from 7 samples of must among 14 tested grape cultivars. The quantity of lactobacilli increased at the end of the $4^{\text {th }}$ week of fermentation (Table 1).

Table 1

Concentration of bacteria from Lactobacillus genus in grape must

\begin{tabular}{|c|c|c|c|c|}
\hline Grape cultivar & 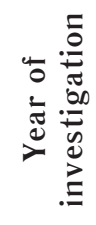 & $\begin{array}{c}\text { Place of grapevine } \\
\text { cultivation }\end{array}$ & 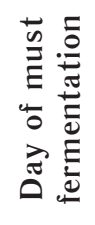 & $\begin{array}{l}\text { Concentration of lactoba- } \\
\text { cilli, CFU } / \mathrm{ml}\end{array}$ \\
\hline \multirow{3}{*}{ Chardonnay } & \multirow{3}{*}{2011} & \multirow{3}{*}{ Odesa } & 2 & $(4,3 \pm 2,8) \times 10^{3}$ \\
\hline & & & 3 & $(4,5 \pm 1,4) \times 10^{3}$ \\
\hline & & & 28 & $(2,3 \pm 1,6) \times 10^{4}$ \\
\hline \multirow{3}{*}{ Lidia } & \multirow{2}{*}{2011} & \multirow{2}{*}{ Odesa } & 2 & $(2,3 \pm 1,8) \times 10^{3}$ \\
\hline & & & 3 & $(4,3 \pm 1,7) \times 10^{4}$ \\
\hline & 2012 & Odesa & 4 & $(1,2 \pm 0,5) \times 10^{5}$ \\
\hline \multirow{3}{*}{ Pinot noir } & \multirow{3}{*}{2011} & \multirow{3}{*}{ Odesa } & 2 & $(2,4 \pm 1,6) \times 10^{4}$ \\
\hline & & & 3 & $(4,2 \pm 2,6) \times 10^{4}$ \\
\hline & & & 28 & $(4,3 \pm 1,6) \times 10^{4}$ \\
\hline Isabella & 2011 & Odesa & 3 & $(4,8 \pm 2,6) \times 10^{4}$ \\
\hline Moldova & 2011 & Odesa & 3 & $(4,3 \pm 2,3) \times 10^{2}$ \\
\hline $\begin{array}{l}\text { Dnistrovskyi } \\
\text { rozhevyi }\end{array}$ & 2012 & $\begin{array}{l}\text { Kiliya district, } \\
\text { Odesa region }\end{array}$ & 12 & $(3,7 \pm 3,6) \times 10^{5}$ \\
\hline Cardinal & 2012 & Odesa & 12 & $(4,1 \pm 1,2) \times 10^{5}$ \\
\hline
\end{tabular}


As it is known from the literature, after some period of time individual for every certain wine material, cells survived after ethanol fermentation, start to multiply. Non desirable multiplication of such microorganisms could happen in vines with $\mathrm{pH}$ higher than 3.5 [2]. Under the conditions of low $\mathrm{pH}$, lactic acid bacteria die rapidly, but when $\mathrm{pH}$ is higher than 3.5 , they can continue to multiply and in concentrations $10^{6}-10^{8}$ cause the spoilage of wines $[2,4]$. In our experiment, fermentation of wine was uncontrolled and carried out under the conditions that favor the proliferation of lactic acid bacteria in must (temperature $18-20^{\circ} \mathrm{C}$, absence of anaerobic conditions necessary for ethanol fermentation).

The isolated strains of lactobacilli were first identified by morphological and biochemical properties. After, PCR-assay with bacterial DNA was carried out. Amplification product of 250 b.p. size was synthesized in the samples of DNA from all the tested strains, and this result revealed presence of $16 \mathrm{~S}$ rRNA fragment specific for the bacteria of Lactobacillus genus. PCR with primers planF/pREV [15] resulted in amplicons 318 b.p. in size in case of $80 \%$ of the tested Lactobacillus strains that confirmed their belonging to the species $L$. plantarum.

It is known that in the beginning of ethanol fermentation in grape must L. plantarum and L. casei are mostly occurred [16]. Besides, the representatives of such species as $L$. brevis, L. hilgardii, L. curvatus and L. buchneri can also be revealed in must [13].

Totally 23 strains of lactic acid bacteria have been isolated from grape must during the investigations; they were identified and studied. In 2011, strains L. plantarum ONU 12, 311, 312 and 313 were isolated from must of Pinot noir cultivated in Odesa. In 2012, strains L. plantarum ONU 341-350 were isolated from grape of Lidia cultivar grown in Odesa. From berries of Cardinal cultivar (Odesa) strains L. plantarum ONU 332-336 and ONU 339, 340 were isolated, and must of Dnistrovskyi rozhevyi cultivated in Kiliya district of Odesa region was the source of the strains L. plantarum ONU 337, 338.

The results of RAPD-PCR showed presence of groups of genetic similarity and diversity between the strains of L. plantarum. As it could be seen from the electrophoretic analysis, amplification products with DNA of the strains isolated from one source (grapevine of Lidia cultivar) were very similar (fig. 1).

The results of cluster analysis based on Spearman's correlation coefficient and the method of Ward used for evaluation the similarity between the studied lactic acid are presented in fig. 2 .

As it could be seen from the presented data, all the strains formed 4 basic clusters grouped by the level of their similarity.

Basing on the obtained data, it can be said that the maximal similarity showed the strains L. plantarum ONU 338 and L. plantarum ONU 340 forming cluster G3 (the percentage of similarity between the strains - 
$65.0 \%$ ) although these strains were isolated from different sources. Strain L. plantarum ONU 338 was isolated from grape of Dnistrovskyi rozhevyi cultivar grown in Kiliya district of Odesa region, and strain L. plantarum ONU 340 - from grape of Cardinal cultivar from Odesa. This allowed us to conclude that the genetic similarity of the strains not always coincided with the territory of grape origin.

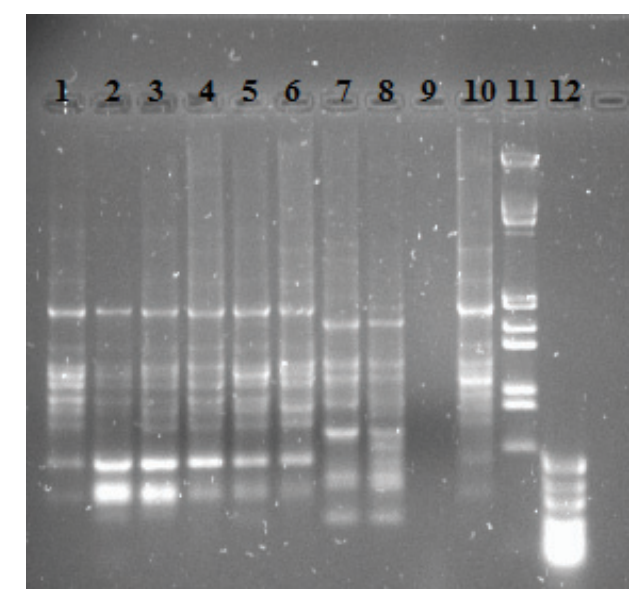

Fig. 1. The electrophoretic analysis of amplicons resulted from RAPD-PCR 1-8,10 - amplicons of RAPD-PCR with DNA from L. plantarum ONU 341, 342, $343,344,345,346,347,348,349$ and 350 , respectively; 11,12 - the markers of molecular weight.

Cluster G1 was formed by the strains from wine material of one cultivar and place of cultivation (Lidia, Odesa) (fig. 2). These are the strains L. plantarum ONU 341, 344, 345, 343, 342, 346 and 350. Three more strains from the same origin were arranged to other clusters. Strains L. plantarum ONU 347 and 348 together with the strains L. plantarum ONU 335 and ONU 334 isolated from wine material of Cardinal cultivar (Odesa) formed the separate cluster G4 with the similarity between the strains from 48.0 to $52.0 \%$.

Strain L. plantarum ONU 349 also isolated from must of Lidia cultivar (Odesa) showed the similarity to the strains forming subcluster G2.4 in a cluster G2. Thus, among the strains L. plantarum from must of Lidia cultivar grown in Odesa three groups of genetic diversity were revealed.

Cluster G2 joined the biggest amount of the studied strains with different levels of similarity forming subclusters G2.1, G2.2, G2.3 and G2.4 (fig. 2). Thus, to subcluster G2.1 strains L. plantarum ONU 313 and 312 from wine material of Pinot noir (Odesa) and strains L. plantarum ONU 332 and 339 from Cardinal cultivar (Odesa) were arranged. Percentage of similarity among the strains in this subcluster was relatively high (from 49.0 to $52.0 \%$ ). Strains L. plantarum ONU 333 and 336 also isolated from must of Cardinal cultivar (Odesa) formed subcluster G2.2 with the percentage of similarity between the strains $50.0 \%$. Subcluster G2.4 joined the 
A.G. Merlich, V.O. Ivanytsia, N.V. Korotaeva, M.A. Zlatogurska, N.Yu. Vasylieva and others

strains L. plantarum ONU 12 and 311 (Pinot noir, Odesa), L. plantarum ONU 349 (Lidia, Odesa) and L. plantarum ONU 337 (Dnistrovskyi rozhevyi, Kiliya district, Odesa region). Similarity between the strains in this case was evaluated as $36.0 \%$.

Such grouping of the strains one more confirmed that the genetic similarity of the strains was not always related to the territorial origin. The control strains L. plantarum UCM B-2694 and L. plantarum UCM B-2709 were ranged to the same cluster G2 (subcluster G2.3), and the level of similarity between them was established as $49.0 \%$ (fig. 2).

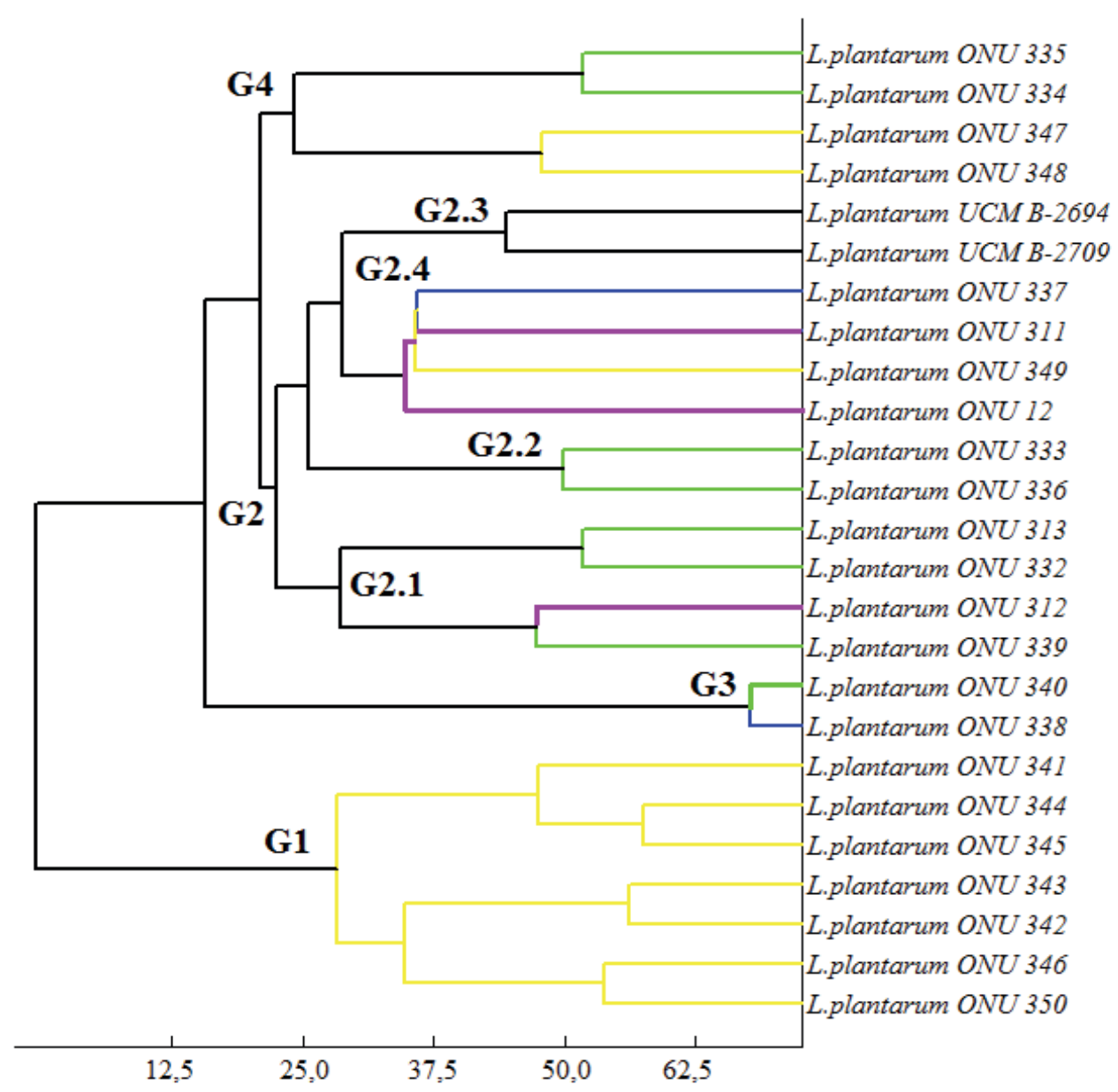

Fig. 2. The results of RAPD-PCR analysis with the primer M13 presented as the phylogenetic reconstruction and grouped by cluster analysis based on Spearman's correlation coefficient and method of Ward (Matlab 7.0).

Cultivars of grapevine are marked in colors:

$\begin{array}{cc}\text { Lidia cultivar, Odesa } & \text { Cardinal, Odesa } \\ & \text { Dnistrovskyi rozhevyi, Kiliya } \\ \text { Pinot noir, Odesa } & \text { district, Odesa region }\end{array}$


Besides this, it is needed to be mentioned that the year of isolation of lactobacilli didn't influence the topology of cluster formation. For instance, strains L. plantarum ONU 313 and 311 were isolated from wine material of Pinot noir (Odesa) in 2011, but according to their genetic properties they were ranged into different subclusters of the cluster G2 (fig. 2).

Genetic diversity of the strains is a common feature of L. plantarum [9]. Thus, it is known that the strains inside the species L. plantarum can differ in presence of various genes responsible for bacteriocin productions and in their variations [10]. Besides, the strains of L. plantarum can also be characterized by the spectrum of antimicrobial activity [1]. The investigators have shown the presence of 7 genetic groups and 18 subgroups in oenological L. plantarum strains from one geographical territory (Spain) [12].

In our case the results of RAPD-PCR with the primer M13 have demonstrated the preferential genetic similarity among the strains of L. plantarum isolated from the certain sample of grape must, but the strains from grape collected in distant territories could also be similar. At the same time, some L. plantarum strains from one source of origin could demonstrate the genetic diversity.

УДК 579.25

А.Г. Мерліч, В.О. Іваниця, Н.В. Коротаєва, М.А. Златогурська, Н.Ю. Васильєва, Д.О. Бабенко, Н.В. Ліманська

Одеський національний університет імені І.І. Мечникова, вул. Дворянська, 2, Одеса, 65082, Україна, e-mail: limanska@gmail.com

\section{LACTOBACILLUS PLANTARUM IЗ ЯГІД ВИНОГРАДУ, ЯКИЙ КУЛЬТИВУЄТЬСЯ НА ПІВДНІ УКРАЇНИ}

\section{Peферат}

Метою дослідження було виділення бактерій Lactobacillus plantarum із ягід винограду та вивчення їх генетичної різноманітності. Матеріали i методи. Молочнокислі бактерії були виділені з ягід 14 сортів винограду, який культивувався на півдні України. Для ідентифікації L. plantarum та вивчення різноманітності штамів застосовували класичний метод ПЛР та RAPD-ПЛP. Для реконструкції філогенетичного дерева досліджених штамів було використано програму Matlab 7.0. Результати. Бактерії роду Lactobacillus були виділені з 7 проб виноградного сусла серед 14 протестованих сортів винограду. 80\% досліджених штамів лактобацил належали до виду L. plantarum. Виявлено групи генетичної схожості між штамами L. plantarum. На філогенетичному дереві штами формували чотири кластери, згруповані за ступенем їх подібності. Вказані результати дозволили зробити висновок про те, що генетично подібними могли бути штами L. plantarum, виділені з виноградного сусла різних сортів та місцевостей 
A.G. Merlich, V.O. Ivanytsia, N.V. Korotaeva, M.A. Zlatogurska, N.Yu. Vasylieva and others культивування винограду. У той же час штами L. plantarum з однакового джерела походження могли виявляти генетичну різноманітність.

Кл юч о в і с л о в а : молочнокислі бактерії, Lactobacillus plantarum, виноградне сусло, RAPD-ПЛР.

А.Г. Мерлич, В.А. Иваница, Н.В. Коротаева, М.А. Златогурская, Н.Ю. Васильева, Д.А. Бабенко, Н.В. Лиманская

Одесский национальный университет имени И.И. Мечникова, ул. Дворянская, 2, Одесса, 65082, Украина, e-mail: limanska@gmail.com

\section{LACTOBACILLUS PLANTARUM ИЗ ЯГОД ВИНОГРАДА, КУЛЬТИВИРУЕМОГО НА ЮГЕ УКРАИНЫ}

\section{Реферат}

Целью исследования было выделение Lactobacillus plantarum из ягод винограда и изучение их генетического разнообразия. Материалы и методы. Молочнокислые бактерии были выделены из ягод 14 сортов винограда, вырощенного на юге Украины. Для идентификации L. plantarum и изучения их разнообразия была использована полимеразная цепная реакция и RAPD-ПЦР. Реконструкция филогенетического дерева была проведена при помощи программы Matlab 7.0. Результаты. Лактобациллы были выделены в 7 пробах сусла из 14 протестированных сортов винограда. $80 \%$ изученных штаммов принадлежали к виду L. plantarum. Были выявлены группы генетического сходства между штаммами L. plantarum. На филогенетическом дереве штаммы образовывали четыре кластера, сгруппированных в соответствии с их подобием. Указанные результаты позволили сделать вывод о том, что штаммы L. plantarum из сусла винограда различных сортов и территорий культивирования винограда могли проявлять генетическое сходство. Напротив, некоторые штаммы L. plantarum из одного источника происхождения могли демонстрировать генетическое разнообразие.

Kлючевы е с лова: молочнокислые бактерии, виноградное сусло, RAPD-PCR.

\section{LITERATURE}

1. Ben Omar N., Abriouel H., Keleke S., Sбnchez Valenzuela A., Martrnez-Cacamero M., Lucas Lypez R., Ortega E., Gбlvez A. Bacteriocin-producing Lactobacillus strains isolated from poto poto, a Congolese fermented maize product, and genetic fingerprinting of their plantaricin operons // International Journal of Food Microbiology. - 2008. - V. 127 P. 18-25.

2. Bou M., Brown N., Costello P., Degre R. Malolactic fermentation in wine. - Lallemand Inc. - Montreal, 2005. - p. 204. 
3. Dellaglio F., Bottazzi V., Vescovo M. Deoxyribonucleic acid homology among Lactobacillus species of the subgenus Streptobacterium OrlaJensen // Int. J. Syst. Bacteriol. - 1975. - Vol. 25. - P. 160-172.

4. du Toit M., Pretorius S. Microbial spoilage and preservation of wine: using weapons from nature's own arsenal - a review // J. Enol. Vitic. 2000. - Vol. 21. - P. 74-96.

5. Dubernet S., Desmasures N., Gueguen M. A PCR-based method for identification of lactobacilli at the genus level // FEMS Microbiology Letters. - 2002. - Vol. 214. - P. 217-275.

6. Fleet G.H. Yeast interaction and wine flavour // Int. J. Food Microbiol. - 2003. - Vol. 86. - P. 11-22.

7. Liu S.-Q. Malolactic fermentation in wine - beyond deacidification // J. Appl. Microbiol. - 2002. - Vol. 92. - P. 589-601.

8. Man J.C., Rogosa M., Sharpe M.E. A medium for the cultivation of lactobacilli // J. Appl. Bacteriol. - 1960. - Vol. 23. - P. 130-135.

9. Molenaar D., Bringel F., Schuren F.H., de Vos W.M., Siezen R.J., Kleerebezem $M$. Exploring Lactobacillus plantarum genome diversity by using microarrays // J. Bacteriol. - 2005. - Vol. 187. - P. 6119-6127.

10. Morteza S.M., Hooi L.F., Thean Ch.L., Raha A.R., Teck Ch.L. Novel Bacteriocinogenic Lactobacillus plantarum Strains and Their Differentiation by Sequence Analysis of 16S rDNA, 16S-23S and 23S-5S Intergenic Spacer Regions and Randomly Amplified Polymorphic DNA Analysis // Food Technol. Biotechnol. - 2010. - V. 48. - P. 476-483.

11. Oh Y., Varmanen P., Han X.Y., Bennett G., Xu Z., Lu T., Palva A. Lactobacillus plantarum for oral peptide delivery // Oral Microbiol Immunol. - 2007. - Vol. 22. - P. 140-144.

12. Saenz Y., Rojo-Bezares B., Navarro L., Diez L., Somalo S., Zarazaga M., Ruiz-Larrea F., Torres $C$. Genetic diversity of the pln locus among oenological Lactobacillus plantarum strains // Int J Food Microbiology. 2009. - Vol. 134. - P. 176-183.

13. Sung Sook Bae. Investigation of bacteria associated with Australian wine grapes using cultural and molecular methods // Thesis for PhD degree. - Sydney, Australia. - 2005. - P. 211.

14. Szegedi E., Bottka S. Detection of Agrobacterium vitis by polymerase chain reaction in grapevine bleeding sap after isolation on a semiselective medium // Vitis. - 2002. - Vol. 41, № 1. - P. 37-42.

15. Torriani S., Felis G.E., Dellagio F. Differentiation of Lactobacillus plantarum, L. pentosus, and $L$. paraplantarum by recA gene sequence analysis and multiplex PCR assay with recA gene-derived primers // Appl. Environm. Microbiol. - 2001. - Vol. 67. - P. 3450-3454.

16. Wibowo D., Eschenbroch R., Davis D., Fleet G., Lu T. Occurrence of growth of lactic acid bacteria in wine: a review // Am. J. Enol. Vitic. 1993. - Vol. 36. - P. 302-313.

Стаття надійшла до редакції 24.08.2013 р. 